\title{
Evolution of Virulence in Fusarium oxysporum f. sp. vasinfectum Using Serial Passage Assays Through Susceptible Cotton
}

\author{
B. Wang, C. L. Brubaker, W. Tate, M. J. Woods, and J. J. Burdon
}

CSIRO Plant Industry, G.P.O. Box 1600, Canberra ACT 2601, Australia.

Accepted for publication 15 October 2007.

\begin{abstract}
Wang, B., Brubaker, C. L., Tate, W., Woods, M. J., and Burdon, J. J. 2008. Evolution of virulence in Fusarium oxysporum f. sp. vasinfectum using serial passage assays through susceptible cotton. Phytopathology 98:296-303.

Fifty strains of Fusarium oxysporum, recovered from rhizosphere soil around native Gossypium species and found to be mildly virulent on cotton (Gossypium hirsutum), were used to assay the propensity for evolution of virulence using serial passage assays through cotton. Only one lineage A strain, 2613, successfully completed 10 successive passages, while all others lost the ability to cause foliar disease symptoms at

various stages during this process. Based on 46 amplified fragment length polymorphism (AFLP) markers generated with four EcoRI $\times M s e \mathrm{I}$ primer combinations, mutants were identified in offspring isolates from strain 2613 regardless of whether serial passages occurred in cotton or on water agar, suggesting the occurrence of spontaneous mutations. Significantly increased virulence was observed in the offspring isolates generated on cotton, while no increasing virulence was found in those obtained on water agar, suggesting that the evolution of virulence in $F$. oxysporum $\mathrm{f}$. sp. vasinfectum is associated with the presence of cotton. No clear correlation was observed between the AFLP mutations and increased virulence in this study.
\end{abstract}

Virulence, defined here as a quantitative measure of pathogenicity denoting the severity of disease caused by a pathogen on a particular host, is an important driving force in host-pathogen interactions $(39,41)$. In the past, "conventional wisdom" and simplistic heuristic arguments proposed that, in natural host-pathogen systems, pathogens should evolve towards reduced virulence or avirulence because damage to hosts is ultimately detrimental to pathogens as virulent pathogens are more likely to drive their hosts, and consequently themselves, to extinction $(3,34)$. The inherent weakness of these arguments, as demonstrated by their apparent reliance on group selection, an unstable theoretical basis, and lack of supporting samples in nature $(24,32)$, is now widely accepted. Virulence is now seen as an unavoidable consequence of pathogens evolving towards maximizing their fitness and, since virulence is genetically correlated with various fitness characteristics, natural selection will favor optimal levels of virulence determined by trade-offs among virulence and transmission modes, reproductive rates, and other life history traits of both the pathogens and hosts involved $(9,32,39,40)$. This view is supported by the demonstration of a negative trade-off between virulence and spore production in the Linum-Melampsora plant-pathogen system where broadly virulent pathogens occur more frequently in highly resistant host populations, while avirulent pathogens dominate susceptible populations (45). Similar results have been found in other plant-pathogen systems (e.g., Danthonia-Atkinsonella hypoxylon and Hordeum vulgare-Rhynchosporium secalis $[1,31])$. However, there are also instances where virulence and fitness of pathogens are uncorrelated $(46,55)$, suggesting that, because relationships between virulence, fitness, and other life history traits are complex, evolution may result in a wide range of strategies for pathogens to cope with various hosts and situations (51). Nevertheless, most pathogens maintain intermediate levels

Corresponding author: B. Wang; E-mail address: Bo.Wang@csiro.au

doi:10.1094/PHYTO-98-3-0296

(c) 2008 The American Phytopathological Society of virulence in natural ecosystems, suggesting that linkage between pathogen transmissibility and pathogen-induced host damage is an important feature producing trade-offs that favor virulence levels around a dynamic optimum $(32,34)$.

In contrast to the evolutionary dynamics of plant pathogens in heterogeneous natural ecosystems, agricultural plant pathogens are under constant selection pressure to respond to the resistance deployed artificially in host plants. This has the potential to significantly alter the intensity of the dynamics of virulence evolution between agroecosystems and natural ecosystems-a concept embodied in "man-guided" evolution of the cereal rusts (26). Indeed, this continuous stream of novel resistances introduced into crop plants by directional breeding is well reflected in many cases of resistance breakdown due to the increased virulence of pathogens $(7,38,40,43)$. While the roles of mutation, recombination, and migration contributing to changes in the virulence of biotrophic pathogen populations (e.g., rusts and mildews) have been well documented (10), the process of virulence evolution in populations of necrotrophic plant pathogens is far less well understood. Indeed, there are only a limited number of field experiments studying pathogen evolution under controllable and repeatable conditions $(1,55)$.

Empirical data are limited because of the difficulty of conducting experimental studies under field conditions where true controls are difficult to institute due to the considerable influence of many biological and ecological processes. Therefore, approaches using controlled systems (i.e., in the glasshouse) are a useful experimental protocol to quantify the genetic events occurring in the process of virulence evolution (53). Serial passage experiments in which pathogens are successively transferred from one host to another is an approach originally developed for viral attenuation but now widely used to investigate the causes and consequences of pathogen evolution by monitoring phenotypic and molecular changes in real time (17). This technique has been successfully used to cast light on the evolution of virulence and fitness of pathogenic fungi including Fusarium graminearum and F. pseudograminearum (2), Rhynchosporium secalis (1), and Septoria nodorum (12). 
F. oxysporum is a ubiquitous, asexual, soilborne fungus that may live both saprophytically or as a destructive pathogen of many economically important crops (6). Pathogenic strains are grouped into formae speciales based on pathogenicity on specific plant species, with $F$. oxysporum f. sp. vasinfectum being the causal agent of Fusarium wilt of cotton (Gossypium hirsutum), a destructive disease that occurs in almost all cotton-producing countries of the world (23). In Australia, F. oxysporum f. sp. vasinfectum was first found in 1993 in the Darling Downs area of Queensland (30), and has now become widespread (49). Previous work showed that the Australian F. oxysporum f. sp. vasinfectum evolved from local origins being genetically related to a lineage of native $F$. oxysporum and differs from all other forms of F. oxysporum f. sp. vasinfectum found overseas $(5,15,29,50)$. Furthermore, pathogenic isolates of $F$. oxysporum collected from rhizosphere soil of wild cotton (Gossypium spp.) around the country showed a considerably lower level of virulence on cultivated cotton than those causing the disease in infested cotton fields (48). This supported the idea that $F$. oxysporum f. sp. vasinfectum in Australia may have evolved from the local pool of less virulent $F$. oxysporum isolates as a result of interactions in long-term monocultures of susceptible cotton cultivars. A number of processes may have contributed to the appearance and spread of $F$. oxysporum f. sp. vasinfectum, e.g., (i) repetitive cultivation of cotton has selected for increasing of virulence; and (ii) local ecological conditions imposed by broad scale cultivation of susceptible cotton cultivars have increased the frequency of highly virulent strains.

In order to develop a deeper understanding of the process of virulence evolution in $F$. oxysporum $\mathrm{f}$. $\mathrm{sp}$. vasinfectum and the role of cotton in this process, here we aimed to (i) determine whether the virulence of pathogenic isolates of native $F$. oxysporum increases after serial passage on susceptible cotton plants; and (ii) quantify the genetic diversity of the offspring population obtained through such serial passages.

\section{MATERIALS AND METHODS}

Fungal strains and cotton cultivar. Fifty single-spore strains were chosen from a large collection of Australian native $F$. oxysporum recovered from soil of wild Gossypium species in previous studies $(48,50)$. They originated from different geographic regions and populations of Gossypium species, and belonged to three genetically distinct lineages (A, B, and E) represented by 15, 17, and 18 strains, respectively (Table 1). All these strains were putatively classified as $F$. oxysporum f. sp. vasinfectum because of their ability to cause slight, but typical, Fusarium wilt symptoms (i.e., vascular discoloration) on susceptible cotton plants when tested in the glasshouse (50). Two isolates of $F$. oxysporum f. sp. vasinfectum (highly virulent 24500 and mildly virulent 24595) recovered from diseased cotton plants in the field and provided by N. Moore and W. O'Neil (Queensland Department of Primary Industries, Indooroopilly, Australia) were used as references in bioassays.

Serial passage assays on cotton and virulence comparison trials were both conducted on the highly susceptible cotton cultivar, Siokra 1-4.

Serial passage assays on cotton. Fusarium strains were grown individually in $75 \mathrm{ml}$ of $25 \%$ potato dextrose broth (PDB, Difco Laboratories, Detroit, MI) in 150-ml flasks, placed on an orbital shaker at $150 \mathrm{rpm}$, at 18 to $23^{\circ} \mathrm{C}$ for 1 week. Inocula were prepared by adding $75 \mathrm{ml}$ of distilled water to cultures. Final spore concentrations, based on hemacytometer counts, ranged from $2.5 \times 10^{5}$ to $8.5 \times 10^{7}$ spores $/ \mathrm{ml}$. Two-week-old cotton seedlings were inoculated by dipping roots in inocula for $5 \mathrm{~min}$. Distilled water and a conidial suspension of the highly virulent reference F. oxysporum f. sp. vasinfectum isolate 24500 were used for noninoculated and positive controls, respectively. These controls were distributed randomly among the experimental pots. Inoculated plants were then transplanted into fresh potting mix (compost and perlite; $50 / 50, \mathrm{vol} / \mathrm{vol}$ ) and grown at 18 to $23^{\circ} \mathrm{C}$ in a naturally lit glasshouse, which was an airconditioned, sealed, $\mathrm{PC} 2$ facility to minimize the influence of external contaminants. Extensive surface-disinfection was carried out using 5\% Biogram (16.5\% ortho-phenylphenol in $2.5 \%$ clorofene; Ecolab, Cheltenham, Australia) before the experiment and between serial passages. Thirty plants were assessed for each strain with three plants per pot. Diseased plants were identified by the appearance of vascular discoloration in stems 6 weeks after inoculation, and the virulence of a strain was quantified by the number of diseased plants it caused among the 30 inoculated plants. Re-isolation was carried out on $25 \%$ PDB from one to three of the most affected plants but only if a strain caused foliar symptoms, i.e., wilting, yellowing, and death. Subsequently, offspring isolates were separately maintained and used to start the next serial passage using the same methodology. After 10 serial cycles, representatives of offspring isolates were compared to their ancestral strain to determine the change in virulence.

Serial passage assays on agar. To complement the serial passage through cotton, one of the 50 ancestral strains, 2613, selected because it was the only strain that completed 10 serial generations through cotton, was serially passaged on water agar. This was done by growing strain 2613 on water agar at $25^{\circ} \mathrm{C}$ for 1 week, after which two single spores were transferred individually onto new plates. These were regarded as the secondary isolates and the whole process was then repeated nine times giving a total of nine serial generations on agar.

AFLP analysis. In this study, AFLP genotyping was used to (i) ensure no switching of isolates or accidental contamination between serial passages, and (ii) determine if genetic changes occurred during the experimental period.

Original strains and offspring isolates were grown in $12 \mathrm{ml}$ of $80 \%$ PDB in $15-\mathrm{ml}$ sterile test tubes at $25^{\circ} \mathrm{C}$ for 3 days. Mycelia were harvested by centrifuging cultures at 3,500 rpm for $15 \mathrm{~min}$, decanting liquid, and transferring pellets onto Whatman No. 1 filter paper to remove excess water. Genomic DNA was extracted from lyophilized mycelia using DNeasy Plant kits (Qiagen Pty Ltd., Clifton Hill, Australia) according to manufacturer instructions.

AFLP fingerprints were generated using the protocol described by Vos et al. (47) with some modifications due to the replacement of radioactive labels by fluorescent dyes. DNA (125 ng) was codigested with $\mathrm{MseI}$ and EcoRI at $37^{\circ} \mathrm{C}$ for $2 \mathrm{~h}$ in $20 \mu \mathrm{l}$ of digestion buffer, and oligomer adapters ligated to DNA fragments at $37^{\circ} \mathrm{C}$ for $3 \mathrm{~h}$ in $40 \mu \mathrm{l}$ of ligation buffer. Pre-selective amplification was performed with $2.5 \mu \mathrm{l}$ of ligation solution in $25 \mu \mathrm{l}$ of PCR buffer containing nonselective primers $M s e \mathrm{I}+0$ and $E c o$ RI+0 ( 20 cycles of $30 \mathrm{~s}$ at $94^{\circ} \mathrm{C}, 60 \mathrm{~s}$ at $56^{\circ} \mathrm{C}$, and $60 \mathrm{~s}$ at $72^{\circ} \mathrm{C}$ ). Selective amplification was performed with $3 \mu \mathrm{l}$ of 1:20 diluted preselective amplification solution in $10 \mu \mathrm{l}$ of PCR buffer containing a primer combination of $\mathrm{Mse} \mathrm{I}+\mathrm{A}$ and 6-carboxyfluoresceinlabelled EcoRI+AGG-FAM, AGT-PET, ACC-VIC, and ACA$\mathrm{NED}$ in independent reactions $\left(1\right.$ cycle of $30 \mathrm{~s}$ at $94^{\circ} \mathrm{C}, 30 \mathrm{~s}$ at $65^{\circ} \mathrm{C}$, and $60 \mathrm{~s}$ at $72^{\circ} \mathrm{C} ; 12$ cycles of $65^{\circ} \mathrm{C}$ with annealing temperature lowered by $0.7^{\circ} \mathrm{C}$ during each cycle; and 23 cycles of $30 \mathrm{~s}$ at $94^{\circ} \mathrm{C}, 30 \mathrm{~s}$ at $56^{\circ} \mathrm{C}$, and $60 \mathrm{~s}$ at $72^{\circ} \mathrm{C}$ ).

Amplified DNA fragments were separated by capillary electrophoresis on an ABI 3130 Genetic Analyzer (Applied Biosystems, Warrington, UK). The size of DNA fragments was determined using GeneScan-500LIZ (Applied Biosystems) as an internal size standard (35 to $500 \mathrm{bp}$ ). Four AFLP profiles, one for each of the four selective primer combinations used, were established for each of the isolates analyzed in this study using GeneMapper version 4.0 (Applied Biosystems).

Virulence comparison trials. Two trials were conducted to determine the virulence of strain 2613 and its offspring isolates 
generated during passage assays on cotton using the same methodology described previously except that inocula spore concentrations were standardized at $5 \times 10^{5}$ spores $/ \mathrm{ml}$. In trial I, 19 offspring isolates including one lineage (C1-b to $\mathrm{C} 10-\mathrm{i})$ generated from 10 passage assays on cotton (Fig. 1) and one lineage (A1-b to A9-j) generated from nine passage assays on agar (Fig. 2) were tested. In trial II, 12 offspring isolates including three generated from the $3 \mathrm{rd}$, four from the $7 \mathrm{th}$, and five from the 10th passage assay on cotton were tested. In both trials, distilled water and conidial suspensions of both reference $F$. oxysporum f. sp. vasinfectum isolates were used for noninoculated and positive controls, respectively. There were three replicates in trial I but five replicates in trial II; 15 plants with three plants per pot were used for each replicate. The numbers of diseased plants were recorded at harvest. All trials were conducted twice.

Data analysis. AFLP profiles were assessed individually, and only unambiguous peaks with over 200 fluorescence units were scored as dominant markers (presence or absence). A binary data matrix was developed by combining all data from four primer combinations and analyzed using NTSYSpc version 2.11X (Exeter Software, Setauket, NY). Haplotypes were determined by calculating the Dice coefficient of genetic similarity in the SIMQUAL module and constructing an unweighted pair-group with arithmetic averages (UPGMA) dendrogram in the SAHN module. Bootstrap values $(10,000$ replicates) were calculated using Winboot (International Rice Research Institute, Manila, Philippines).

Analyses of variance of the data from virulence comparison trials were performed using the general linear model of GenStat 9th Edition (VSN International, Hemel Hempstead, UK). Data from repeated trials were combined for analysis after tests for equal variances. Means were compared using Duncan's protected least significant difference with $P<0.05$.

\section{RESULTS}

Serial passage assays. Of the 50 ancestral strains used in the first assay on cotton, only eight (seven lineage A and one lineage E) strains caused foliar symptoms and were passed to the second

TABLE 1. Strains of Fusarium oxysporum used in this study

\begin{tabular}{|c|c|c|c|c|}
\hline Strain & Geographic origin $^{a}$ & Host species & Lineage & No. of passage \\
\hline 1543 & Mt. Isa, QLD & G. nelsonii & $\mathrm{B}$ & 0 \\
\hline 1602 & Mt. Isa, QLD & G. nelsonii & $\mathrm{B}$ & 0 \\
\hline 2503 & Barrow Creek, NT & G. sturtianum & $\mathrm{B}$ & 0 \\
\hline 2601 & Alice Springs, NT & G. bickii & $\mathrm{B}$ & 0 \\
\hline 2613 & Undoolya, NT & G. sturtianum & A & 10 \\
\hline 2620 & Atnarpa, NT & G. sturtianum & $\mathrm{B}$ & 0 \\
\hline 2631 & Ross River Tourist Camp, NT & G. sturtianum & $\mathrm{E}$ & 0 \\
\hline 2638 & Tea Tree, NT & G. australe & $\mathrm{B}$ & 0 \\
\hline 3501 & Teatree OS, SA & G. sturtianum & A & 0 \\
\hline 3506 & Teatree OS, SA & G. sturtianum & $\mathrm{E}$ & 0 \\
\hline 3508 & Teatree OS, SA & G. sturtianum & A & 0 \\
\hline 3509 & Teatree OS, SA & G. sturtianum & $\mathrm{E}$ & 0 \\
\hline 3512 & Teatree OS, SA & G. sturtianum & $\mathrm{E}$ & 0 \\
\hline 3515 & Teatree OS, SA & G. sturtianum & $\mathrm{B}$ & 0 \\
\hline 3520 & Tindelpina Hut, SA & G. sturtianum & A & 7 \\
\hline 3521 & Tindelpina Hut, SA & G. sturtianum & $\mathrm{B}$ & 0 \\
\hline 3533 & Copley, SA & G. sturtianum & $\mathrm{E}$ & 0 \\
\hline 3534 & Copley, SA & G. sturtianum & A & 0 \\
\hline 3535 & Mulga View, SA & G. sturtianum & $\mathrm{E}$ & 1 \\
\hline 3538 & Mulga View, SA & G. sturtianum & $\mathrm{B}$ & 0 \\
\hline 3542 & Mulga View, SA & G. sturtianum & A & 0 \\
\hline 3543 & Mulga View, SA & G. sturtianum & $\mathrm{E}$ & 0 \\
\hline 3546 & Grindell Hut, SA & G. sturtianum & $\mathrm{A}$ & 0 \\
\hline 3547 & Grindell Hut, SA & G. sturtianum & $\mathrm{A}$ & 0 \\
\hline 3552 & Mulga View, SA & G. sturtianum & $\mathrm{E}$ & 0 \\
\hline 3556 & Tindelpina Hut, SA & G. sturtianum & A & 8 \\
\hline 3558 & Mulga View, SA & G. sturtianum & A & 1 \\
\hline 3570 & Mulga View, SA & G. sturtianum & A & 4 \\
\hline 3572 & Grindell Hut, SA & G. sturtianum & $\mathrm{A}$ & 0 \\
\hline 3574 & West Mount Hut, SA & G. sturtianum & $\mathrm{E}$ & 0 \\
\hline 3580 & Mulga View, SA & G. sturtianum & $\mathrm{E}$ & 0 \\
\hline 3581 & Tindelpina Hut, SA & G. sturtianum & $\mathrm{E}$ & 0 \\
\hline 3585 & Mulga View, SA & G. sturtianum & $\mathrm{B}$ & 0 \\
\hline 3587 & Mulga View, SA & G. sturtianum & $\mathrm{E}$ & 0 \\
\hline 3588 & Nilpena, SA & G. sturtianum & $\mathrm{A}$ & 1 \\
\hline 3607 & Grindell Hut, SA & G. sturtianum & $\mathrm{E}$ & 0 \\
\hline 3621 & Grindell Hut, SA & G. sturtianum & $\mathrm{E}$ & 0 \\
\hline 4511 & Theodore, QLD & G. sturtianum & $\mathrm{E}$ & 0 \\
\hline 4520 & Theodore, QLD & G. sturtianum & $\mathrm{B}$ & 0 \\
\hline 4524 & Theodore, QLD & G. sturtianum & $\mathrm{E}$ & 0 \\
\hline 4535 & Emerald, QLD & G. sturtianum & $\mathrm{B}$ & 0 \\
\hline 4537 & Emerald, QLD & G. sturtianum & $\mathrm{E}$ & 0 \\
\hline 4565 & Barcaldine, QLD & G. australe & $\mathrm{B}$ & 0 \\
\hline 4590 & Braidwood, QLD & G. australe & $\mathrm{E}$ & 0 \\
\hline 4598 & Glenariff, QLD & G. sturtianum & $\mathrm{B}$ & 0 \\
\hline 4608 & Glenariff, QLD & G. sturtianum & $\mathrm{B}$ & 0 \\
\hline 4625 & Muswellbrook, NSW & G. sturtianum & $\mathrm{A}$ & 0 \\
\hline 6515 & Boggabilla, NSW & Other plant species & $\mathrm{B}$ & 0 \\
\hline 6521 & Boggabilla, NSW & Other plant species & A & 1 \\
\hline 6575 & Talwood, QLD & Other plant species & $\mathrm{B}$ & 0 \\
\hline
\end{tabular}

${ }^{\mathrm{a}} \mathrm{QLD}=$ Queensland; SA = South Australia; NT = The Northern Territory; NSW = New South Wales. 
cycle. Among these eight strains, strain 6521 was isolated from soil collected from a native vegetation site in New South Wales, while all others were isolated from soil collected from around G. sturtianum populations in the Northern Territory and South Australia (Table 1). Only one strain, 2613, successfully passed through 10 cycles on cotton, while all others lost their ability to cause foliar symptoms at various stages during the serial passage process. Nevertheless, variation in virulence was observed in the strain 2613 lineage and the others which failed to complete all serial passages, although some of that variation was probably caused by differences in the environmental conditions under which the assays were conducted (Table 2). Further work focused on strain 2613 and its offspring isolates since this was the only strain that completed 10 serial passage assays.

Forty-seven offspring isolates were obtained from strain 2613 in serial passage assays conducted on water agar (Fig. 2).

AFLP analysis. A total of 136 isolates were genotyped in this study, including strain 2613 and a subsample of its offspring isolates from passage assays on cotton (88 isolates) and water agar (47 isolates) as shown in Figures 1 and 2. Forty-six unambiguous polymorphic markers were identified due to their absence in at least one isolate. Of these markers, 12 were observed in offspring isolates from both cotton and agar; 33 markers were found only in isolates cycled on cotton, and one marker was found only in isolates cycled on water agar (Table 3).

Compared with fingerprints of strain 2613, 16 haplotypes representing 22 mutants were identified among the 135 offspring isolates genotyped in this study (Figs. 1, 2, and 3). Fourteen mutant haplotypes were found among the 88 offspring isolates passaged through cotton, while only three mutant haplotypes were detected among the 47 offspring isolates from water agar. Only one haplotype (C6-i and A5-e) was found among the offspring isolates of both sources (Fig. 3). There were no clear phylogenetic relationships between these mutant offspring isolates (Figs. 1 and 2). For example, two mutant isolates generated from the 9th passage assay on cotton (C9-a and C9-f) occurred in the same haplotype (Fig. 3), but their ancestors (C1-a and C1-b) had already been separated since the 2nd assay (Fig. 1).

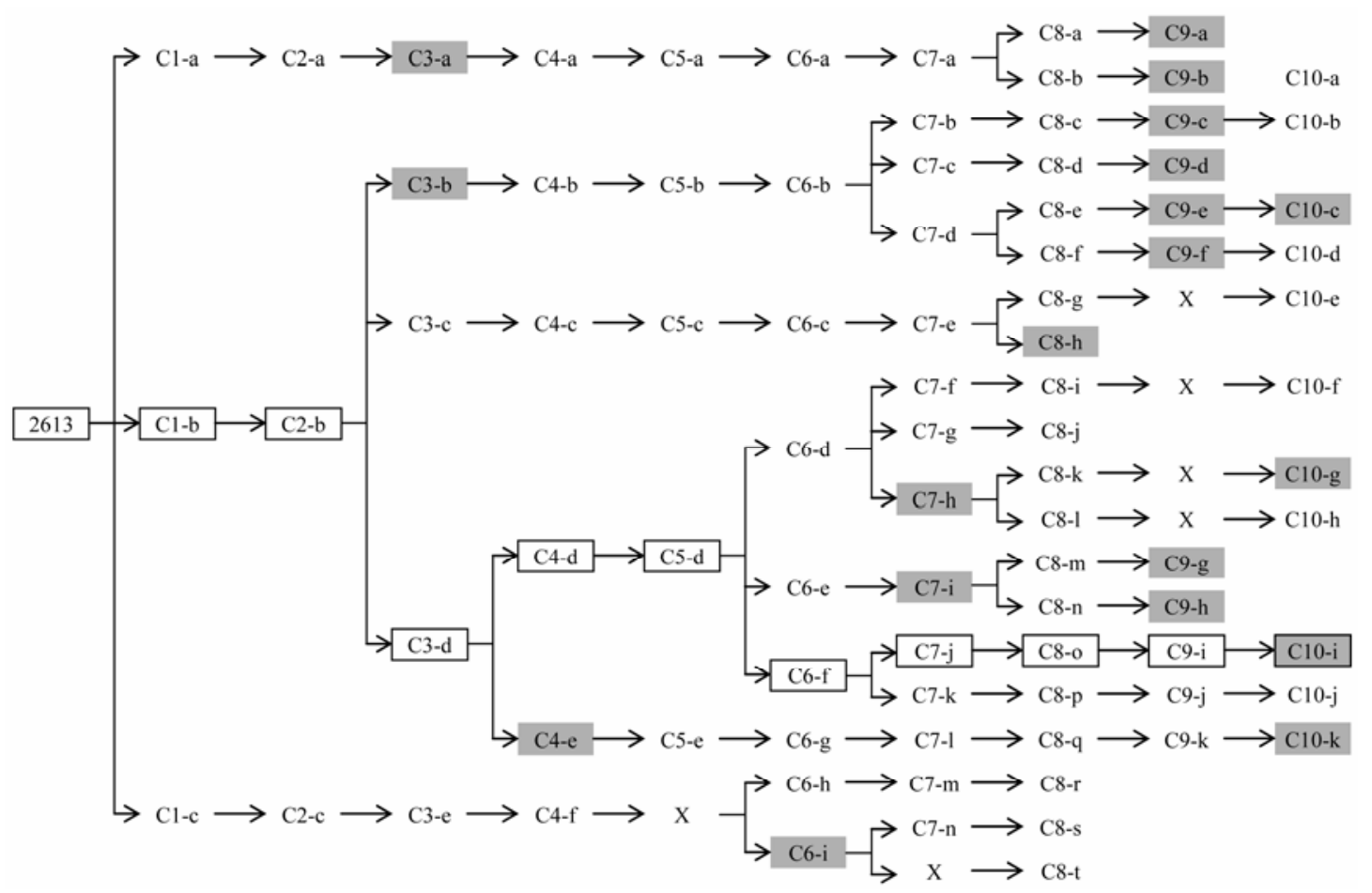

Fig. 1. A subsample of 88 offspring isolates of the ancestral strain 2613 generated from serial passage through cotton. Isolates in open boxes were used in virulence comparison trial I, and those in shaded boxes were mutants identified based on 46 fluorescent amplified fragment length polymorphism markers. ' $\mathrm{X}$ ' means the offspring isolate was not genotyped due to unsuccessful polymerase chain reaction.

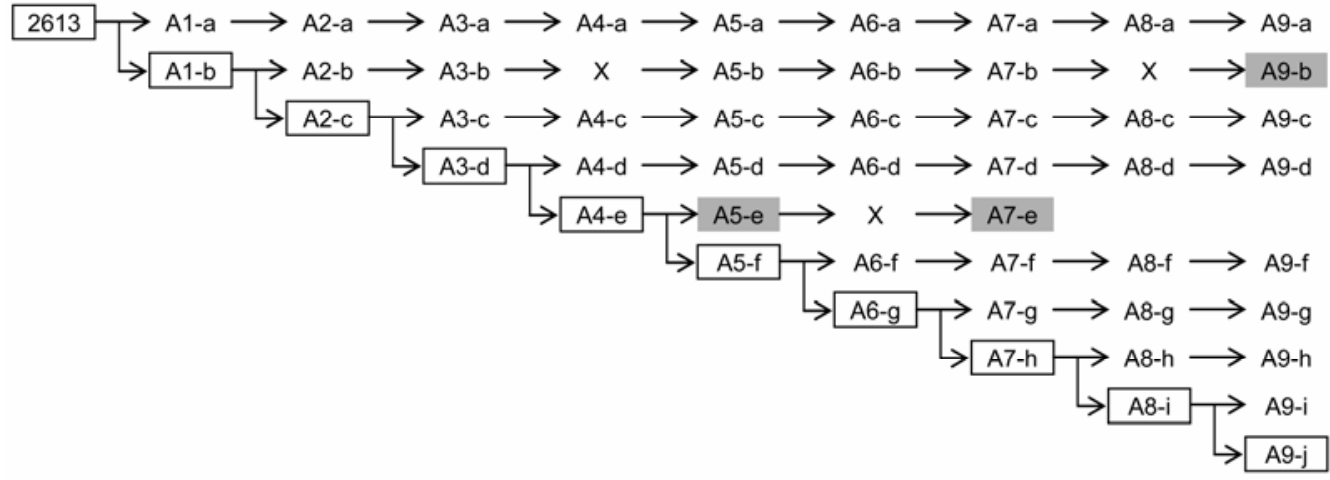

Fig. 2. A subsample of 47 offspring isolates of the ancestral strain 2613 generated from serial passage on water agar. Isolates in open boxes were used in virulence comparison trial I, and those in shaded boxes were mutants identified based on 46 fluorescent amplified fragment length polymorphism markers. 'X' means the offspring isolate was not genotyped due to unsuccessful polymerase chain reaction. 
Virulence comparison trials. In trial I, no significant difference in virulence was observed in offspring isolates generated from the first three passage assays regardless of source. However, from the 4th assay on, offspring isolates from cotton generally showed higher virulence than those from agar. A significant difference in virulence was found between offspring isolates of different sources from the 9th assay, while the offspring isolate from the 10th assay on cotton (C10-i) was even more virulent than those from previous assays (Fig. 4).

The virulence of 12 offspring isolates obtained from the 3rd, 7 th, and 10th passage assays, respectively, was compared in trial II. When these isolates were grouped based on passages, no significant difference was observed between the ancestral strain and any of the three groups (data not shown). However, when individual isolates were compared, the virulence of isolates $\mathrm{C} 10-\mathrm{h}$ and C10-i (3.5 and 2.7) was significantly higher than the virulence of both the ancestral strain (1.6) and other offspring isolates used in the trial (ranging from 0.1 to 1.8$)\left(P<0.01 ; \mathrm{LSD}_{0.01}=\right.$ 0.93) (Fig. 5).

\section{DISCUSSION}

This study provides empirical evidence that the evolution of virulence in $F$. oxysporum f. sp. vasinfectum occurs in a continuous process. As offspring isolates from the most diseased plants were serially passaged on cotton, virulence was observed to gradually increase in some lineages (Fig. 4), suggesting the successive accumulation of mutations for increased virulence. The pattern of continuous incremental increase in virulence has previously been reported in $F$. oxysporum f. sp. ciceris, the pathogen causing Fusarium wilt of chickpea (25). The process of virulence evolution may be obscured by parallel gains or losses of virulence. Thus, there are at least three gains and two losses for the evolution of virulence in F. oxysporum f. sp. ciceris, although a general trend toward increasing virulence is evident (25). In contrast to this process of continuous evolution characterized by repeated small increases in virulence, in biotrophic fungi where interactions between pathogens and their hosts are frequently controlled by gene-for-gene arrangements, changes in pathogenicity are typified by stepwise changes from avirulence to virulence responses to specific host resistance genes. Thus, Puccinia striiformis $\mathrm{f}$. sp. tritici, the pathogen causing yellow rust of wheat in Australia and New Zealand, has acquired virulence in this way with all recently identified pathotypes derived from an initial single introduction and differing between each other at single virulence loci $(44,52)$.

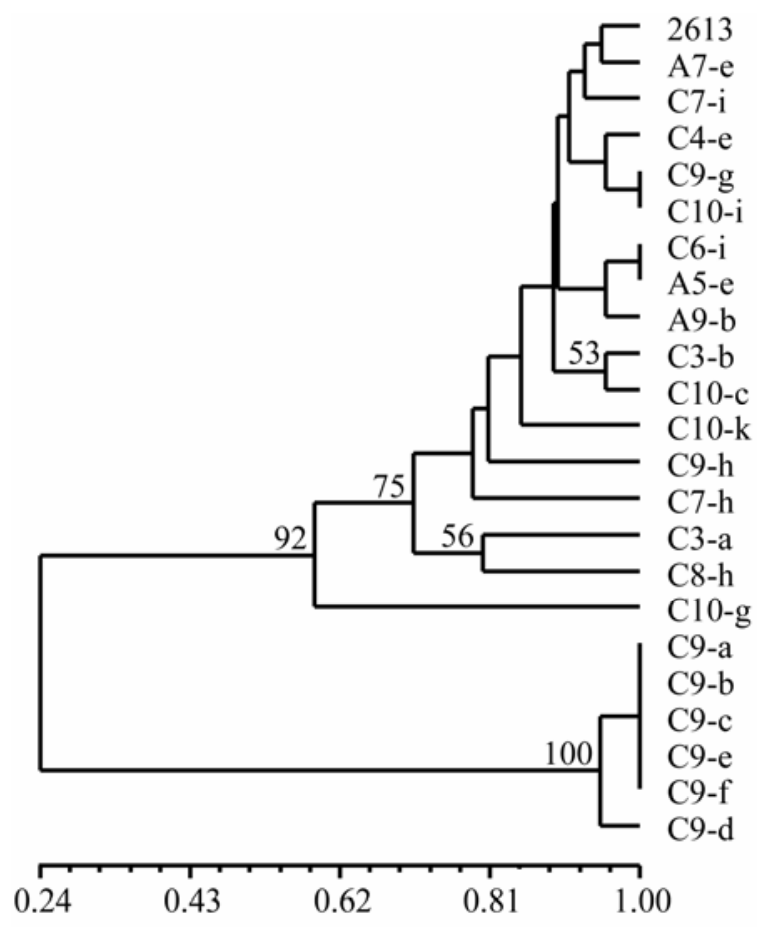

Dice coefficient

Fig. 3. Dendrogram based on the Dice coefficient constructed by unweighted pair-group method with arithmetic average cluster analysis of 46 polymorphic fluorescent amplified fragment length polymorphism (AFLP) markers from the ancestral strain 2613 and 22 mutant offspring isolates generated with four fluorescent AFLP primer combinations. Bootstrap values ( $>50 \%)$ from 10,000 replicates analysis are shown above nodes.

TABLE 2. Summary of eight ancestral strains of Fusarium oxysporum f. sp. vasinfectum that caused foliar symptoms and their families obtained from serial passage on cotton

\begin{tabular}{|c|c|c|c|c|c|c|c|c|c|c|c|c|c|}
\hline \multirow[b]{2}{*}{ Lineage } & \multirow[b]{2}{*}{ Strain } & \multicolumn{11}{|c|}{ Highest level of virulence observed in different passage assays ${ }^{\mathrm{a}}$} & \multirow{2}{*}{$\begin{array}{l}\text { Family } \\
\text { size }^{\mathrm{b}}\end{array}$} \\
\hline & & Original & 1 & 2 & 3 & 4 & 5 & 6 & 7 & 8 & 9 & 10 & \\
\hline A & 2613 & 4 & 7 & 8 & 15 & 11 & 7 & 13 & 13 & 10 & 10 & 6 & 748 \\
\hline A & 3570 & 3 & 3 & 2 & 2 & 1 & $\mathrm{X}$ & & & & & & 9 \\
\hline A & 3558 & 3 & $X$ & & & & & & & & & & 2 \\
\hline A & 3588 & 1 & $X$ & & & & & & & & & & 2 \\
\hline
\end{tabular}

${ }^{a}$ Represented by the greatest number of diseased plants caused by an offspring isolate on 30 inoculated plants.

${ }^{\mathrm{b}}$ Represented by the total number of offspring isolates generated from an ancestral strain.

c Passage ceased because no foliar symptoms were caused.

TABLE 3. Primer combinations used for fluorescent amplified fragment length polymorphism analysis, the number of total polymorphic markers of molecular size ranging from 50 to $500 \mathrm{bp}$, and the number of markers observed in offspring isolates from serial passage on cotton, agar, and both

\begin{tabular}{lcccc}
\hline Primers & Polymorphic markers & $\begin{array}{c}\text { Markers only in offspring } \\
\text { isolates from cotton }\end{array}$ & $\begin{array}{c}\text { Markers only in offspring } \\
\text { isolates from agar }\end{array}$ & $\begin{array}{c}\text { Markers found in offspring } \\
\text { isolates from both }\end{array}$ \\
\hline EcoRI-AGG / MseI-A & 7 & 5 & 1 & 1 \\
EcoRI-AGT / MseI-A & 14 & 10 & 0 & 4 \\
EcoRI-ACC / MseI-A & 14 & 10 & 0 & 4 \\
EcoRI-ACA / MseI-A & 11 & 8 & 0 & 3 \\
Total & 46 & 33 & 1 & 12 \\
\hline
\end{tabular}


The controls of both biotic and abiotic variables in this study ensured that any virulence changes detected in offspring isolates resulted from evolutionary changes within the isolates in response to selective pressures imposed by the host plant. The lack of molecular variation in offspring isolates with increased virulence (Fig. 1) is consistent with the fact that mutation rates at virulence loci are higher than those at the molecular loci that define genotypes (21). A similar observation was also reported in Rhynchosporium secalis (22). On the other hand, it is possible that the changes in virulence were caused by changes in epigenetic states of the fungus as a consequence of the responses to host shift and environmental stress.

As the most important evolutionary force in asexually reproducing pathogens, mutation is the ultimate source of genetic variation that both creates new strains to overcome major gene resistance and increases virulence of existing strains to erode minor gene or quantitative resistance (35). The mechanisms underlying mutations include substitution, insertion, and deletion at the nucleotide level as well as rearrangement and modification at the genome level. In this study, the high mutation frequency and unrelated distribution of mutants in offspring isolates are unexpected (Figs. 1 and 2), suggesting that mutations were probably associated with the movement of transposable elements (transposons) which have been identified in the genome of $F$. oxysporum, where they cause spontaneous mutations causing changes in virulence $(13,36)$. However, although mutations caused by transposon movement may occur at high frequency, they are unstable and easily reversible (20). This is consistent with the unpredictability of occurrence of particular mutants since no vertical

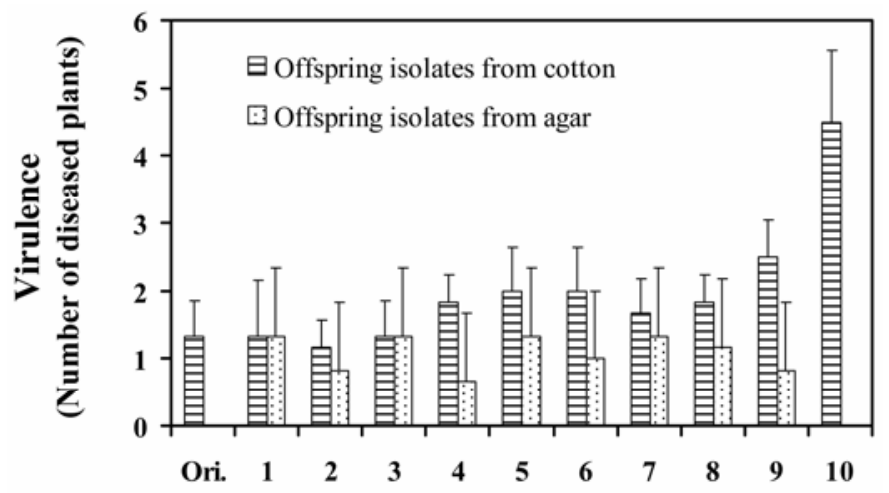

Passage of the offspring isolate obtained

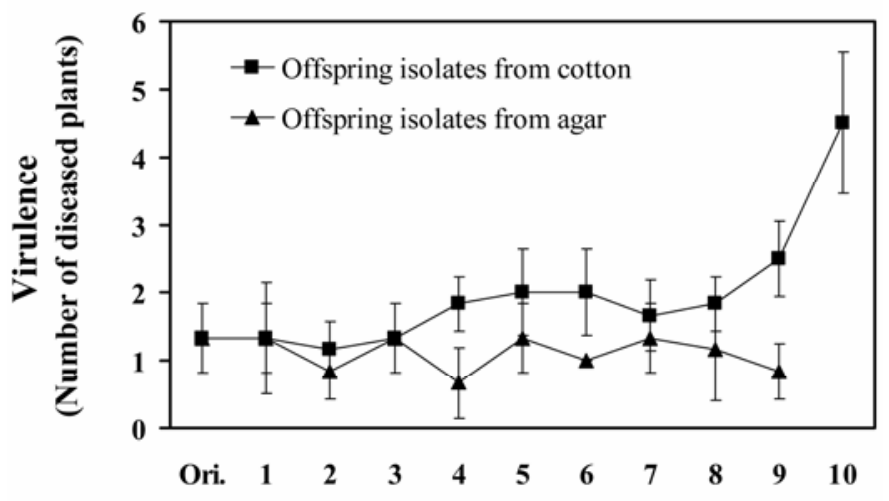

Passage of the offspring isolate obtained

Fig. 4. Variation of virulence in two lines of offspring isolates of the ancestral strain 2613 generated from serial passages on cotton and agar. Virulence is represented by the number of plants that became diseased out of 15 inoculated plants. The values are mean of six replicates from two independent trials. Ori. $=$ original. The bars are standard deviations. (intergenerational) relationships were found between identical mutants in this study. For instance, offspring isolates C9-a, b, c, e, and $f$ are identical mutants as shown on Figure 3, but they derived from different wild-type isolates in the 8th passage (Fig. 1). In addition, the two vertically related mutant isolates (C9-e and C10c; Fig. 1) found in this study are genetically less related to each other (Fig. 3), while in most cases wild-type isolates were recovered from diseased plants inoculated with mutants. This is probably because transposons can restore wild-type alleles without leaving "footprints" in revertant isolates. Gómez- Gómez et al. (19) reported that restriction patterns of revertants from nit mutants of $F$. oxysporum f. sp. lycopersici were identical to that of the wild-type strain as a result of the absence of the transposon Folyt 1, previously present in the mutants. Given that no evidence for relationships between AFLP mutations and increased virulence was observed in this study, and that transposition may result in reduced virulence or even avirulence of pathogen strains $(8,16)$, the lack of vertical relationships between mutants generated from the passage assays on cotton could be explained by the unsuccessfully passaged mutants being out-competed by wild-type revertants in the inocula that were used to inoculate plants in the next series. Perhaps reversion occurs at a considerably high frequency in mutants since a similar phenomenon was also observed in mutants generated from the passage assays on water agar although no selective pressures were applied in trial II. Similarly, high genetic instability of transposon-induced mutants was observed in $F$. oxysporum with over $10 \%$ mutants for nitrate reductase gene reverted to wild type (14).

Genetic changes with no known relationship to increased virulence were observed in offspring isolates obtained in this study (Fig. 3). Among the 22 mutants, a significant increase in virulence only occurred in one offspring isolate, C10-i (data for others not shown). This reflects the lack of association between virulence traits and the particular AFLP markers assessed. A similar lack of association has been shown in many other fungal pathogens $(28$, $37,42)$, although a clear correlation was found in Mycosphaerella graminicola (54). Interestingly, mutant isolates C9-g and C10-i were genetically identical but significantly different in virulence, suggesting that the changes in virulence found in this study probably resulted from epigenetic changes that were heritable in gene expression (phenotype), but occurred without a change in DNA sequence (33). On the other hand, it is possible that the mutants detected in this study resulted from selection against unnecessary virulence genes due to the shift of their host from native Gossypium to cultivated cotton. That the host plant had an important role in providing a selective sieve to drive pathogen

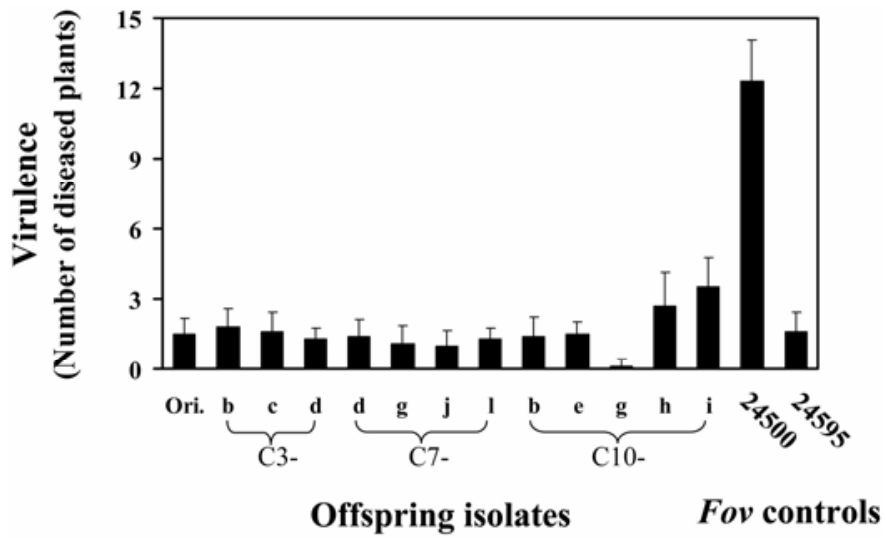

Fig. 5. Virulence of offspring isolates of the ancestral strain 2613 generated from the $3 \mathrm{rd}, 7 \mathrm{th}$, and 10th serial passage on cotton. Virulence is represented by the number of plants that became diseased out of 15 inoculated plants. The values are mean of 10 replicates from two independent trials. Ori. = original. Each column represents an isolate, and the bars, standard deviations. The last two columns are reference field isolates of F. oxysporum f. sp. vasinfectum. 
evolution is shown in the significant increase in virulence observed in offspring isolates serially cultured through cotton in contrast to the lack of significant changes in virulence associated with isolates cultured in water agar (Fig. 4).

Local origins of new pathotypes from either existing races or local populations of nonpathogenic strains have been found in F. oxysporum f. spp. melonis and lycopersici; the pathogens causing Fusarium wilt of melon and tomato, respectively $(4,11$, 18,27, ,). In Israel, race 2 of $F$. oxysporum f. sp. melonis appeared to have arisen from race 0 in VCG 0135 (27). Similarly, in California, race 3 of $F$. oxysporum $\mathrm{f}$. sp. lycopersici appeared to have arisen from race 2 in the same VCG $(11,18)$. In Maryland, race 1 of $F$. oxysporum f. sp. melonis in VCG 0131 may have evolved recently because it was more related to local nonpathogenic $F$. oxysporum isolates than to other forms of the pathogen (4). In Australia, Fusarium wilt of cotton was first reported in 1993 (30), and two strains of $F$. oxysporum f. sp. vasinfectum now occur in diseased cotton fields (49). AFLP analyses and gene genealogies suggest local origins for these strains because they are genetically distinct from other strains of $F$. oxysporum f. sp. vasinfectum found overseas while being closely related to lineage A of Australian native $F$. oxysporum (50). This interpretation is consistent with the reaction of lineage A strains in serial passage assays of this study. The frequency of strains causing foliar symptoms was considerably higher in lineage A ( 7 out of 15 ; $47 \%$ ) than in lineage E (1 out of $18 ; 6 \%$ ) and lineage B (none out of $17 ; 0$ ), and all four strains that successfully transmitted their increased virulence to offspring are lineage A (Table 2). Furthermore, a significant increase in virulence was observed in offspring isolates of lineage A strain 2613, generated from the serial passage assays on cotton (Fig. 4). We postulate that this process reflects the evolutionary history of $F$. oxysporum f. sp. vasinfectum in Australia, and also highlights the risk that new strains of F. oxysporum f. sp. vasinfectum will arise in the future as a consequence of long-term, continuous association with cotton, given the widespread of lineage A strains of $F$. oxysporum in Australian cotton field soil (unpublished data).

\section{ACKNOWLEDGMENTS}

We gratefully acknowledge the support of the Cotton Research and Development Corporation of Australia.

\section{LITERATURE CITED}

1. Abang, M. M., Baum, M., Ceccarelli, S., Grando, S., Linde, C. C., Yahyaoui, A., Zhan, J., and McDonald, B. A. 2006. Differential selection on Rhynchosporium secalis during parasitic and saprophytic phase in the barley scald disease cycle. Phytopathology 96:1214-1222.

2. Akinsanmi, O. A., Chakraborty, S., Backhouse, D., and Simpfendorfer, S. 2007. Passage through alternative hosts changes the fitness of Fusarium graminearum and Fusarium pseudograminearum. Environ. Microbiol. 9:512-520.

3. Alexander, M. 1981. Why microbial predators and parasites do not eliminate their prey and host. Annu. Rev. Microbiol. 35:113-133.

4. Appel, D. J., and Gordon, T. R. 1994. Local and regional variation in populations of Fusarium oxysporum from agricultural field soils. Phytopathology 84:786-791.

5. Bentley, S., Kochman, J. K., Moore, N. Y., Pattemore, J. A., Gulino, L., and O'Neill, W. T. 2000. DNA diagnostics for fusarium wilt of cotton. Pages 455-461 in: Proc. 10th Australian Cotton Conference. Australian Cotton Growers Research Association (ACGRA), Narrabri.

6. Booth, C. 1971. The Genus Fusarium. Commonwealth Agricultural Bureau, Farnham Royal, UK.

7. Brown, J. K. M., Foster, E. M., and O'Hara, R. B. 1997. Adaptation of powdery mildew populations to cereal varieties to durable and nondurable resistance. Pages 119-138 in: The Gene-for Gene Relationship in PlantParasite Interactions. I. R. Crute, E. B. Holub, and J. J. Burdon, eds. CAB International, Wallingford, UK.

8. Brown, J. S., and Holden, D. W. 1998. Insertional mutagenesis of pathogenic fungi. Curr. Opin. Microbiol. 1:390-394.

9. Bull, J. J. 1994. Perspective: Virulence. Evolution 48:1423-1437.
10. Burdon, J. J., and Silk, J. 1997. Sources and patterns of diversity in plantpathogenic fungi. Phytopathology 87:664-669.

11. Cai, G., Gale, L. R., Schneider, R. W., Kistler, H. C., Davis, R. M., Elias, K. S., and Miyao, E. M. 2003. Origin of race 3 of Fusarium oxysporum $\mathrm{f}$. sp. lycopersici at a single site in California. Phytopathology 93:10141022.

12. Cunfer, B. M. 1984. Changes of virulence of Septoria nodorum during passage through barley and wheat. Ann. Appl. Biol. 104:61-68.

13. Daboussi, M.-J., and Langin, T. 1994. Transposable elements in the fungal plant pathogen Fusarium oxysporum. Genetica 93:49-59.

14. Daboussi, M.-J., Langin, T., and Brygoo, Y. 1992. Fot 1, a new family of fungal transposable elements. Mol. Gen. Genet. 232:12-16.

15. Davis, R. D., Moore, N. Y., and Kochman, J. K. 1996. Characterisation of a population of Fusarium oxysporum f. sp. vasinfectum causing wilt of cotton in Australia. Aust. J. Agric. Res. 47:1143-1156.

16. Dufresne, M., Bailet, J. A., Dron, M., and Langin, T. 1998. clk1, a serine/threonine protein kinase-encoding gene, is involved in pathogenicity of Colletotrichum lindemuthianum on common bean. Mol. PlantMicrobe Interact. 11:99-108.

17. Ebert, D. 1998. Experimental evolution of parasites. Science 282:14321435 .

18. Elias, K. S., and Schneider, R. W. 1991. Vegetative compatibility groups in Fusarium oxysporum f. sp. lycopersici. Phytopathology 81:159-162.

19. Gómez-Gómez, E., Anaya, N., Roncero, M. I. G., and Hera, C. 1999. Folyt1, a new member of the hAT family, is active in the genome of the plant pathogen Fusarium oxysporum. Fungal Genet. Biol. 27:67-76.

20. Goodwin, S. B., Cavaletto, J. R., Waalwijk, C., and Kama, G. H. J. 2001. DNA fingerprint probe from Mycosphaerella graminicola identifies an active transposable element. Phytopathology 91:1181-1188.

21. Goodwin, S. B., Sujkowski, L. S., and Fry, W. E. 1995. Rapid evolution of pathogenicity within clonal lineages of the potato late blight disease fungus. Phytopathology 85:669-676.

22. Goodwin, S. B., Webster, R. K., and Allard, R. W. 1994. Evidence for mutation and migration as sources of genetic variation in populations of Rhynchosporium secalis. Phytopathology 84:1047-1053.

23. Hillocks, R. J. 1992. Fusarium wilt. Pages 127-160 in: Cotton Diseases. R. J. Hillocks, ed. CAB International, Wallingford, UK.

24. Jarosz, A. M., and Davelos, A. L. 1995. Effects of disease in wild plant populations and the evolution of pathogen aggressiveness. New Phytol. 129:371-387.

25. Jiménez-Gasco, M. M., Milgroom, M. G., and Jiménez-Díaz, R. M. 2004. Stepwise evolution of races in Fusarium oxysporum $\mathrm{f}$. sp. ciceris inferred from fingerprinting with repetitive DNA sequences. Phytopathology 94:228-235

26. Johnson, T. 1961. Man-guided evolution in plant rusts. Science 133:357362.

27. Katan, T., Katan, J., Gordon, T. R., and Pozniak, D. 1994. Physiologic races and vegetative compatibility groups of Fusarium oxysporum $\mathrm{f}$. $\mathrm{sp}$. melonis in Israel. Phytopathology 84:153-157.

28. Kelemu, S., Skinner, D. Z., Badel, J. L., Moreno, C. X., Rodriguez, M. X., Fernandes, C. D., Charchar, M. J., and Chakraborty, S. 1999. Genetic diversity in South American Colletotrichum gloeosporioides isolates from Stylosanthes guianensis, a tropical forage legume. Eur. J. Plant Pathol. 105:261-272.

29. Kim, Y., Hutmacher, R. B., and Davis, R. M. 2005. Characterization of California isolates of Fusarium oxysporum f. sp. vasinfectum. Plant Dis. 89:366-372.

30. Kochman, J. K. 1995. Fusarium wilt in cotton - A new record in Australia. Australas. Plant Pathol. 24:74.

31. Kover, P. X., and Clay, K. 1998. Trade-off between virulence and vertical transmission and the maintenance of a virulent plant pathogen. Am. Nat. 152:165-175.

32. Lenski, R. E., and May, R. M. 1994. The evolution of virulence in parasites and pathogens: Reconciliation between two competing hypotheses. J. Theor. Biol. 169:253-265.

33. Martienssen, R. A., and Colot, V. 2001. DNA methylation and epigenetic inheritance in plants and filamentous fungi. Science 293:1070-1074.

34. May, R. M., and Anderson, R. M. 1983. Epidemiology and genetics in the coevolution of parasites and hosts. P. Roy. Soc. Lond. B 219:281-313.

35. McDonald, B. A., and Linde, C. 2002. Pathogen population genetics, evolutionary potential, and durable resistance. Annu. Rev. Phytopathol. 40:349-379.

36. Migheli, Q., Steinberg, C., Vadière, J.-M., Olivain, C., Gerlinger, C., Gautheron, N., Alabouvette, C., and Daboussi, M.-J. 2000. Recovery of mutants impaired in pathogenicity after transposition of Impala in Fusarium oxysporum f. sp. melonis. Phytopathology 90:1279-1284.

37. Montarry, J., Corbiere, R., Lesueur, S., Glais, I., and Andrivon, D. 2006. Does selection by resistant hosts trigger local adaptation in plantpathogen systems? J. Evol. Biol. 19:522-531.

38. Parisi, L., Lespinasse, Y., Guillaumes, J., and Krüger, J. 1993. A new race 
of Venturia inaequalis virulent to apple with resistance due to the gene $V f$. Phytopathology 83:533-537.

39. Parker, I. M., and Gilbert, G. S. 2004. The evolutionary ecology of novel plant-pathogen interactions. Annu. Rev. Ecol. Evol. S. 35:675-700.

40. Park, R. F., Bariana, H. S., Wellings, C. R., and Wallwork, H. 2002. Detection and occurrence of a new pathotype of Puccinia triticina with virulence for Lr24 in Australia. Aust. J. Agric. Res. 53:1069-1076.

41. Read, A. F. 1994. The evolution of virulence. Trends Microbiol. 2:73-76.

42. Rodriguez-Guerra, R., Ramirez-Rueda, M. T., de la Vega, O. M., and Simpson, J. 2003. Variation in genotype, pathotype and anastomosis groups of Colletotrichum lindemuthianum isolates from Mexico. Plant Pathol. 52:228-235.

43. Sprague, S. J., Balesdent, M. H., Brun, H., Hayden, H. L., Marcroft, S. J., Pinochet, X., Rouxel, T., and Howlett, B. J. 2006. Major gene resistance in Brassica napus (oilseed rape) is overcome by changes in virulence of populations of Leptosphaeria maculans in France and Australia. Eur. J. Plant Pathol. 114:33-40.

44. Steele, K. A., Humphreys, E., Wellings, C. R., and Dickinson, M. J. 2001. Support for a stepwise mutation model for pathogen evolution in Australasian Puccinia striiiformis f. sp. tritici by use of molecular markers. Plant Pathol. 50:174-180.

45. Thrall, P. H., and Burdon, J. J. 2003. Evolution of virulence in a plant host-pathogen metapopulation. Science 299:1735-1737.

46. Tooley, P. W., Sweigard, J. A., and Fry, W. E. 1986. Fitness and virulence of Phytophthora infestans isolates from sexual and asexual populations. Phytopathology 76:1209-1212.

47. Vos, P., Hogers, R., Bleeker, M., Reijans, M., van de Lee, T., Hornes, M., Frijters, A., Pot, J., Peleman, J., Kuiper, M., and Zabeau, M. 1995. AFLP:
A new technique for DNA fingerprinting. Nucleic Acids Res. 23:44074414.

48. Wang, B., Brubaker, C. L., and Burdon, J. J. 2004. Fusarium species and Fusarium wilt pathogens associated with native Gossypium populations in Australia. Mycol. Res. 108:35-44.

49. Wang, B., Brubaker, C. L., Tate, W., Woods, M. J., Matheson, B. A., and Burdon, J. J. 2006. Genetic variation and population structure of Fusarium oxysporum f. sp. vasinfectum in Australia. Plant Pathol. 55:746755 .

50. Wang, B., Brubaker, C., L., Thrall, P. H., and Burdon, J. J. 2007. Origin and evolution of Fusarium oxysporum $\mathrm{f}$. sp. vasinfectum: A case study in Australia. In press in: World Cotton Research Conference 4 Proc. International Cotton Advisery Committee (ICAC), Washington DC.

51. Weiss, R. A. 2002. Virulence and pathogenicity. Trends Microbiol. 10:314-317.

52. Wellings, C. R., and McIntosh, R. A. 1990. Puccinia striiiformis f. sp. tritici in Australasia: Pathogenic changes during the first 10 years. Plant Pathol. 39:316-325

53. Zhan, J, and McDonald, B. A. 2004. The interaction among evolutionary forces in the pathogen fungus Mycosphaerella graminicola. Fungal Genet. Biol. 41:590-599.

54. Zhan, J., Linde, C. C., Jürgens, T., Merz, U., Steinebrunner, F., and McDonald, B. A. 2005. Variation for neutral markers is correlated with variation for quantitative traits in the plant pathogenic fungus Mycosphaerella graminicola. Mol. Ecol. 14:2683-2693.

55. Zhan, J., Mundt, C. C., Hoffer, M. E., and McDonald, B. A. 2002. Local adaptation and effect of host genotype on the rate of pathogen evolution: An experimental test in a plant pathosystem. J. Evol. Biol. 15:634-647. 